Pragmatism and Psychologism

\title{
Jung and Peirce
}

Towards a Psychosynthesis?

\section{Giovanni Maddalena}

\section{(2) OpenEdition}

\section{Journals}

Electronic version

URL: http://journals.openedition.org/ejpap/1005

DOI: 10.4000/ejpap.1005

ISSN: 2036-4091

Publisher

Associazione Pragma

Electronic reference

Giovanni Maddalena, « Jung and Peirce », European Journal of Pragmatism and American Philosophy [Online], IX-1 | 2017, Online since 22 July 2017, connection on 11 June 2020. URL : http://

journals.openedition.org/ejpap/1005; DOI : https://doi.org/10.4000/ejpap.1005

This text was automatically generated on 11 June 2020 .

\section{(c) $(1) \&$}

Author retains copyright and grants the European Journal of Pragmatism and American Philosophy right of first publication with the work simultaneously licensed under a Creative Commons AttributionNonCommercial-NoDerivatives 4.0 International License. 


\title{
Jung and Peirce
}

\author{
Towards a Psychosynthesis?
}

\author{
Giovanni Maddalena
}

1 As correctly noticed by Vincent Colapietro, one of the few authors who have approached the topic, pragmatism and psychoanalysis followed parallel paths (Colapietro 2006: 191). As much as the two movements were facing similar problems and cultural contexts, they did not cross their footsteps nor scholars have been particularly interested in comparing their approaches and solutions. The distance is understandable also from a historical perspective. When James met Freud at Clark University in 1909 he was not impressed even though he thought that Freud's enquiry was worth being pursued. ${ }^{1}$ Freud thought Jamesian-like observations on religion to be "unscientific" rising only James's despise (Colapietro 2006: 198). ${ }^{2}$ Morevoer, Peirce's continuous attacks to Sigwart's psychologism in logic took the separation between pragmatism and the analysis of psyche even further.

2 However, a different and less obvious comparison between psychoanalysis and pragmatism might be more fruitful. In his book Psychological Types, Jung has a chapter on James's tender-minded/tough-minded distinction (Jung 2009: ch. 8). Jung misunderstands pragmatism as a sort of utilitarianism, but he highly praises James for having understood the two types and having had the courage to apply them to the history of philosophy. Moreover, even though he criticizes James's bias in favor of the tough-minded empiricist, Jung really thinks that the way to a complete self, a balanced outcome of our conscious and unconscious personal universes, has to be somehow "pragmatic" before being authentically creative (Jung 2009: 254). In fact, in abandoning Freudian orthodoxy Jung develops a form of psychoanalysis that takes a distance from the positivist background that runs underneath Freud's approach. That is why Jung's analysis might be an easier ground of comparison with pragmatism. On the pragmatist side, it is Peirce's view, rather than James', to make an uberous parallel with psychoanalysis possible. ${ }^{3}$ Peirce clarifies his aversion to psychologism as years went by. But an attentive reading can tell that his attitude was due more to an improper mixing up of disciplines in analyzing reasoning than to a denial of the importance of psychological traits in our reasoning. Therefore, only by looking at Peirce's philosophy 
in its entirety we are able to grasp the importance that psychology has for Peirce, so that a comparison of pragmatism and psychoanalysis can be conducted on more solid grounds. In this way, we will see that Peirce's interest for psychology shifts from its role into logical analysis to a more comprehensive use within a synthetic pattern. As we are going to see, this unusual comparison is due to the strong epistemic and philosophical import of Jung's mature theories as well as to Peirce's tendency to provide a general theory of the mind, both conscious and unconscious. ${ }^{4}$ Therefore, this paper will try to understand the attitude that Peirce had towards psychology (I), to recall the part of Jung's theory that has to do with Peirce's pragmatism (II), to assess the relationship between the two authors and the reciprocal advantage in mutually integrate their theories (III). I hope in this way to help opening a new terrain for some contemporary developments of psychotherapy.

\section{A Chronological Look at Peirce's Attitude Toward Psychology}

3 In the anti-Cartesian series written in the 1860s Peirce tackles the issue of human knowledge intertwining logical and psychological reasons even though he always held an anti-psychologist attitude in logic. As it is well known, Peirce denies any form of intuition and any power of knowing reality directly. We know everything through the mediation of signs and there is no knowledge without this mediation. Therefore, psychologism understood as a way to ground logic upon the functioning of the psyche is denied. On the contrary, the functioning of mind relies upon the logic of signs. ${ }^{5}$ Notwithstanding this general picture of knowledge, Peirce's discourse is often using psychological elements. In describing knowledge in this way, Peirce also denies any distinction between the noumenon and the phenomenon hitting to a sort of mild idealism in which a phenomenological base is transformed into signs. In showing his arguments sometimes he refers to experiments derived from descriptive psychology as the one of the coin that disappears from our sight in certain circumstances or to the psychological convictions with which we often misinterpret our inferential knowledge (EP1: 5, and 15). Moreover, a first outcome of this revolutionary way of thinking reflects itself on what we now consider the realm of psychology. In the paper Some Consequences of Four Incapacities Peirce remarks that the ego has not such a decisive role in a reality that has to be understood as an infinite flood of signs. Rather, we understand subjectivity in a derivative way, by ignorance:

Accordingly, just as we say that a body is in motion, and not that motion is in a body we ought to say that we are in thought, and not that thoughts are in us. (EP1: 42)

The individual man, since his separate existence is manifested only by ignorance and error, so far as he is anything apart from his fellows, and from what he and they are to be, is only a negation. (EP1: 55)

Some years later, writing the celebrated series in which he states the pragmatic maxim, Peirce identifies our beliefs with the satisfaction of getting rid of irritating doubts. As much as the way to gain beliefs, to fix them, and to clarify our ideas is a logical one, the description of the doubt heavily relies on a psychological approach, provided that at that time psychology was in a inchoative state in which it was difficult to discriminate it from medicine and philosophy. (EP1: 114)

4 During the 1880s, the discovery of the logic of relatives, the study of mathematical continuity, and the attention to the phenomenological base of signs lead Peirce to 
accept a metaphysical realism. By that term Peirce originally understood the logicalontological continuity between reality and knowledge. He contrasted it to nominalism, namely the attitude of thought that leaves a gap between reality and any form of acquiring knowledge. In this realist framework, he writes a sketch of a book that should have been called "A Guess at the Riddle" (1887-88) and the series for The Monist in the years 1891-93. In these works he devotes some significant paragraphs to the application of his phenomenological categories (firstness, secondness, and thirdness) to psychology. In the draft of "A Guess at the Riddle" Peirce recalls Kant's traditional view on psychology (EP1: 257-62). According to it, psychology is divided in three parts: feeling, willing, knowing. He will match those distinctions with more sophisticated, phenomenological nuances so that they will become in both series of writings 1) feeling, 2) sensation, 3) habit of action. The account of these trichotomy follows Peirce's phenomenological observations. Feeling is what is a pervasive unity in which we are immersed. The smell of coffee during drowsiness or an emotion that takes our brain away completely for a while could account for what Peirce means. When a distinction between subject and object arises, when feeling meets some resistance, which is simply anything that is not itself, a second arises. This secondness can have two forms. The more passive one is molition, the sensation that something else is operating on us understood as subjects. Molition is the regular way in which we accept the world of phenomena around us. Only in special cases we intervene exerting a more active role. We name these moments as volition, which is only a special case of secondness. Finally, when we need to introduce a third comprehensive element in order to make sense of a situation, like when we need an interpreter between two speakers with different languages or a lawyer between the client and the judge, we are in the realm of thirdness. Introducing a third element means to create a habit of action, namely an embodied path in which the two elements can enter into a relationship. Thinking is one of our habits of action. For the sake of this paper it is worth noticing that when Peirce introduces his third element, he also gives a logical account of it. In fact, he identifies the introduction of a third element with a synthetical operation (EP1: 260). Synthesis is here the logical function that presides over the taking of a habit of action. I would translate this operation as "recognizing an identity" between two different elements. If we take these two elements as two moments of the same object (or more generally, and pragmatistically, of the same experience), we will gain a description of synthesis as "recognizing an identity through change" linking together the problem of continuity and the semiotic/logical one. ${ }^{6}$ It is also worth noticing that in all his logical writings Peirce gives as granted that the logical path of semiosis and its synthetical processes are working both at conscious and unconscious levels, as he makes clear in explaining the abducitve logic of perceptual judgments (EP2: 226-33). Self-control and consciousness describe only one part of the complex path of our epistemic processes. ${ }^{7}$ They rise at the level of normative sciences but not at a phenomenological level where, according to his previous descriptions, we can find psychological elements.

5 At the turn of century, Peirce is working on his new classification of science (EP2: 258-62). The idea of classification is an old positivist dream, but Peirce needs it because he has to clarify the role that the different disciplines he has introduced play in the system of science. In this classification, among many other tasks, he finally disentangles phenomenology and psychology, at least as far as their definitions as sciences are concerned. Phenomenology is part of philosophy and provides the basic principles of the entire department of philosophy and special sciences, receiving its 
principles only from mathematics. It is a fundamental theoretical science. Psychology is special science, that gives contents to many disciplines, philosophy included, but that needs all those disciplines for its own principles. Put in this way, psychology disappears from the hard kernel of philosophy. The reason for this exclusion is that Peirce wants to take distance from Sigwart's approach to logic. The German thinker, always negatively quoted by the American philosopher, said that at the bottom of our logical inferences there must be a "feeling" that enables us to recognize what is true. Peirce could not accept that inferences had to rely upon a "feeling" because inferences find their justification in the pragmatic maxim. They find their justification forward and not backward (EP2: 244-5). Peirce confirms his line of thought in 1911 when, in the failed attempt of writing an introduction to the republication of the 1870s series and in "A Sketch of Logical Critics," he tries to avoid the psychologism of the satisfaction/ dissatisfaction language referred to belief. He stresses the dependence of belief from reality saying that "there is no different belief that could long maintain itself in his mind, while he remains sane, unless, indeed, he should discover that the real state of facts was quite contrary to his belief" (EP2: 456). If one wished beliefs to change without any relationship with states of fact, he would be insane, and would need no "alcohol or cocaine or anything else that might make you a more complete fool than you care to be" (EP2: 456).

6 MS 645 and some letters to William James seem to confirm this change. Here Peirce assumes all those psychological characteristics as feeling, sensation, and habits of action within the phenomenological categories now defined as "prebits," while psychology is a special science that shares with phenomenology its relying on observation, but has now become "Psychology Proper, by which I mean the Empirical Science of the Modes of Functioning of finite Minds" (EP2: 501). Therefore, Peirce's consideration of psychology clarifies by passing from a form of inclusion within the heart of logic (the 1860s and 1870s series) to a total exclusion as empirical science preoccupied of the functioning of mind. However, he never misses the importance of feeling, sensation, and habits of actions. He keeps considering them as fundamental by shifting their study from a mixed phenomenological/psychological realm to a clearly only-phenomenological discipline. Moreover, he never fails to consider these elements in their working at both conscious and unconscious levels. In the meanwhile, Peirce develops a profound metaphysical realism so that the underplaying of ego's claims and of any a priorism becomes more and more relevant to his philosophy. Peirce conceives metaphysical realism as a complex and continuous interplay between ontologicallogical modalities (possibility, actuality, necessity) that determine the growth of "concrete reasonableness," the embodiment of rationality through history. In this way, any individual, including human individuals, is but a realization of this infinite continuous of reality. The ego is really a small thing in this overwhelming development of reality. His power is only to allow or not allow some actualizations by assenting or not to the path of reality as it presents itself to him. The ego cannot have the claim to master reality but only to be or not to be part of some specific path that reality is taking. In answering to the signs that reality pushes upon him/her, the ego accomplishes also the task of becoming himself/herself:

There is a celebrated passage in the second edition of the Kritick der Reinen Vernunft and a very notable one, in which Kant says that the "I think" - Das Ich Denke - must be able to accompany all his ideas, "since otherwise they would not thoroughly belong to me." A man less given to discoursing might remark on 
reading this: "For my part, I don't hold my ideas as my ownty-downty; I had rather they were Nature's and belonged to Nature's author." However, that would be to misinterpret Kant. In his first edition, he does not call the act "the I think" but "the object=x." That which that act has to effect is the consecution of ideas; now, the need of consecution of ideas is a logical need and is due not, as Kant thinks, to their taking the form of the Urtheil, the assertion, but to their making an argument; and this is not "I think" that always virtually accompanies an argument, but it is: "Don't you think so?" (MS 636: 24-6, 1909)

7 However, the difficult relationship between generals and individuals remains one of the central topics of Peirce's mature research. He never succeeded in giving an adequate proof of the mathematical continuum that he envisaged but he succeeded in giving a logical example of the kind of entanglement between generals and individuals in the existential graphs. In this iconic logic, Peirce proved that there is a way of reasoning which happens through our drawings diagrams (Maddalena 2015: 30-42; Zalamea 2010). The actual scribing is part of the transformation of indeterminate principles into general logical laws. The semiotic study of how the diagram has to be in order to fulfill its task is one of Peirce's most important achievements to which he referred as "my chef d'oeuvre" (CP 4.347). In the existential graphs we see the actualization of Peirce's metaphysical realism even though Peirce himself did not realize that they opened up a new way of conceiving reasoning itself, starting from synthesis. As we are going to see, the new synthesis at which the graphs hinted was more open to include psychological characteristics avoiding the problematic disentangling of phenomenology and psychology that Peirce had to undertake in his late years.

\section{Jung's Parallel (Metaphysical?) Realism}

8 As soon as he detached himself from Freud's orthodoxy, Jung started thinking to the self in a different broader way. He accepted the powerful recognizing of the unconscious that Freud's research uncovered. However, he did not want to think of it as the "trash can" of the familiar novel to which a certain reading of Freud could reduce it (Jung et al. 1964: 32). ${ }^{8}$ Unconscious is not simply an individualistic item, as Jung understood through the study of psychoses (Jung 1983: 65-7, and 214). While in neuroses Freud's method of recalling past traumas and repressions seems to work in many cases, in psychoses the method reveals itself as insufficient. Observation of his psychotic patients led Jung to understand that they were referring to a much broader unconscious whose traces you can find in all human wisdom testimonies, from religious to mythical texts, from poetry to alchemy (Jung 1983: 238-9). Therefore, Jung understood the unconscious as collective, a product of the entire history of humanity.

9 This collective unconscious is full of archetypes, which are potential forms of representation that anybody brings within himself/herself (Jung 1983: 68-71, and 84-5, and 2007). Shadow, animus, anima, the old man, the hero are some of those figures that are alive into the collective unconscious and that determine much of our emotional behavior in both our dreams and memories. The life of this collective unconscious is chaotic and potential. Its symbols are an immense flux that develops through history. The task of the formation of personality is to give order and meaning or, at least, to keep together this huge symbolic reality: 
Consciousness grows out of an unconscious psyche which is older than it, and which goes on functioning together with it or even in spite of it. (Jung 1983: 218)

Man can live the most amazing things if they make sense to him. But the difficulty is to create that sense. It must be a conviction, naturally; but you find that the most convincing things man can invent are cheap and ready-made, and are never able to convince him against his personal desires and fears. (Jung 1983: 90)

The difference between dream and awake is the kind of grasp of this symbolic, rich continuous. In our dreams, we are not controlling it. In the same way, in psychoses the self fails to give an order or a unity to this powerful, chaotic, emotional flux that "possesses" it.

The material of a neurosis is understandable in human terms, but that of psychosis is not [...] neurotic contents can be integrated without appreciable injury to the ego, but psychotic ideas cannot. They remain inaccessible, and ego-consciousness is more or less swamped by them. They even show a distinct tendency to draw the ego into their "system." Such cases indicate that under certain conditions the unconscious is capable of taking over the role of the ego [...]. This tendency to autonomy shows itself above all in affective states, including those of normal people. When in a state of violent affect one says or does things which exceeds the ordinary. Not much is needed: love and hate, joy and grief, are often enough to make the ego and the unconscious to change places [...]. Groups, communities, and even whole nations can be seized in this way by psychic elements. (Jung 1983: 214-5)

11 In Jung's view, selfhood becomes the goal of life, since to attain it we have to balance the conscious and the unconscious parts of our personality.

I use the term "individuation" to denote the process by which a person becomes a psychological "in-dividual," that is, a separate indivisible unity or "whole" [...] the whole must necessarily include not only consciousness but the illimitable field of unconscious occurrences as well, and that the ego can be no more than the center of the field of consciousness. (Jung 1983: 212-3)

On the one hand, as I said before, the task of individuation is tantamount to give order or meaning to the chaotic potential that is the collective unconscious, full of its archetypes. On the other hand, the task means to undermine the conscious egocentered claims that tend to exclude violently the unconscious life with all its emotional richness and its safeguarding warnings for the future. Therefore, individuation is a search for meaning which is all but individualistic. Meaning is something that we "create" only by working on the infinite flux of the collective unconscious in which we are born.

How the harmonizing of conscious and unconscious data is to be undertaken cannot be indicated in the form of a recipe. It is an irrational life-process which expresses itself in definite symbols. It may be the task of the analyst to stand by this process with all the help he can give. In this case, knowledge of the symbols is indispensable, for it is in them that the union of conscious and unconscious contents is consummated. (Jung 1983: 226)

The different inclination towards listening to the ego involved in the actual reality of life and objects and to the profound claim of the archetypes of the unconscious leads to the celebrated psychological types that Jung reckoned as the extroverted and the introverted (Jung 2009: 15-8). The first is more determined from external objects also in the way in which he organizes the internal symbols while the second one is more determined by the internal symbols that he reverses on the exterior. It is no wonder that Jung tried to find these two types along the entire human history giving a sort of history of consciousness. In this task, he finds James's two kinds of philosophers (Jung 
2009: 238-54). Jung read the tender minded Jamesian philosopher as a form of realist and, according to his classification, as an introverted. On the contrary, he saw the tough-minded as a nominalist and extroverted. Loyal to the result of his psychoanalysis, also on himself, Jung criticized James's preference for the toughminded and saw the necessity to find a balance between the two types. Similarly to Peirce's view of "taking habit," balance is a synthetic movement. Individuation is a "synthetic process" (Jung 2013: 66). However, in a way Jung focuses upon the synthetic instance trying to find a way to see the personality at work in the task of becoming a self. As in Peirce's graphs, Jung finds a way to analyze the synthesis while it is happening. This is the role of the drawing and the study of mandalas, ancient Buddhist representations of cosmos. Drawing mandalas is the way in which we can see our self in its formation, during the difficult path toward selfhood, beyond the egocentric consciousness and the chaotic, collective unconscious.

When I began drawing the mandalas, however, I saw that everything, all the paths I had been following, all the steps I had taken, were leading back to a single point namely, to the mid-point. It became increasingly plain to me that the mandala is the center. It is the exponent of all paths, it is the path to the center, to individuation [...]. Its meaning in alchemy is somewhat similar, inasmuch as it represents the synthesis of four elements which are forever tending to fall apart [...]. Their object is the self in contradistinction to the ego, which is only the point of reference for consciousness, whereas the self comprises the totality of psyche altogether, i.e., conscious and unconscious. (Jung 1983: 234-7)

\section{A First, Rough Comparison and Its Usefulness}

The beginning of a comparison between Jung and Peirce includes realism, fallibilism, symbolism, and "gestures" as existential graphs and mandalas.

First, realism. Both Peirce and Jung consider the self as immersed within a flux of reality that has a broad range of phenomenological, logical, and ontological, constitutive elements. Dreams and traditions, science and alchemy, poetry and experiments, books, characters, facts, thoughts, feelings, habits are all elements of reality or, as pragmatists used to say, of "experience." There is no dualism between spiritual and corporeal for both pragmatists and Jung. Contrary to Freud, in this view Jung could accept symbols, religious sentiments, or beliefs as constitutive parts of experience (Jung 1983: 58). This rich realism is meta-physical, technically speaking. It shares many characteristics with Duns Scotus' metaphysical, medieval realism. ${ }^{9}$ Pragmatists tend to focus on the conscious part of experience but is Peirce himself who recognizes that there must be an unconscious level and to attribute to it the same semiosis that happens at a conscious level. Peirce acknowledges a quasi-mind and a reasoning that happens below the threshold of consciousness. ${ }^{10}$ Moreover, many times Peirce refers to the collective experience of humanity that precedes us. ${ }^{11}$ In his article Issues of Pragmaticism, Peirce acknowledges the root of common sense itself in this collective, sedimented experience (EP2: 349). James follows Peirce's steps when he says that "our fundamental ways of thinking about things are discoveries from exceedingly remote ancestors, which have been able to preserve themselves throughout the experience of all subsequent time" (James 1921: 170). On the other hand, confirming the relationship with an ancient metaphysical realism, Jung does not hesitate to call the 
unconscious as a reality: "We call the unconscious 'nothing,' and yet it is a reality in potentia" (Jung 1983: 216).

Second, Peirce downplays the role and the importance of the ego by ascribing many functions to the ongoing semiotics to which the ego belongs. Moreover, he understands that the small fraction of the continuous flux of reality that human beings can acknowledge and the limited semiotic with which we can develop our knowledge make our knowledge deeply fallible. Even though we often find in Jung a more individualist approach, the substantial difference that he stresses between the ego understood as the center of the conscious personality and the self as the goal of the entire personality that deals with both conscious and unconscious approaches the Swiss psychiatrist to the American philosopher. Also for Jung, selfhood is an order to attain within a broader flux of experience. The self is not the starting engine and creator of knowledge but a point of passage and sometimes of transformation of a much broader history of a collective unconscious.

For indeed our consciousness does not create itself - it wells up from unknown depths. In childhood it awakens gradually, and all through life it wakes each morning out of the depths of sleep from an unconscious condition. It is like a child that is born daily out of the primordial womb of the unconscious. (Jung 1983: 417)

17 Third, the symbolic level is fundamental in both authors. Peirce's lifelong research on symbols as the kind of sign that represents its object by interpretation could help clarifying many practical and theoretical tools that Jung uses as myths, dreams, and archetypes. Archetypes are potential forms of representation:

The archetype in itself is empty and purely formal, nothing but a facultas praeformandi, a possibility of representation which is given a priori. The representations themselves are not inherited only the forms, and in that respect they correspond in every way to the instincts, which are also determined in form only. (Jung 1983: 155)

They are akin to the phenomenological ground of signs but it is clear that they fulfill themselves taking symbolic representations in myths, dreams, etc. Jung's detachment from Freud began exactly with the different appreciation of the symbolic value of libido in the case of incest (Jung 1983: 58). Moreover, Jung acknowledges the temporal development of unconscious symbols that are both historical and teleologically driven (Jung 1983: 216-7). Peirce's semiotic can explain the drive toward completion, namely the intrinsic teleology of symbols, from a technical point of view, avoiding Jung's sometimes esoteric formulations. This technical characteristic would account for the "prophetic" role of our unconscious, one of the most striking aspects of Jung's analysis, with which the Swiss psychiatrist recalls and amends the entire history of the interpretation of dreams. More in general, Peirce's account of semiosis and kinds of signs can help clarifying the symbolic representation of our unconscious strengthening Jung's interpretation of symbols.

19 Fourth, the need of a different synthesis and of synthetic gestures emerge from both authors. It is this fourth point that this paper wants to stress. Given the strong metaphysical realism and the strong symbolism that they share, both Peirce and Jung need an embodiment of this broad reality of experience into the singular experience of the individual. Peirce tried to solve the crucial dilemma of the universal and the singular through mathematical studies of the continuum. He thought that individuals were a discontinuity within a continuity but he tried to make sense of them by new interpretations and demonstrations of the mathematical continuum. He failed but he 
envisaged a sort of possible path of research through existential graphs. In a complementary way, Jung saw in individuation a completion of his realism, avoiding from the beginning an interpretation of it as discontinuity. Jung found in mandalas a way to figure out this unity of universality and individuality. Both existential graphs and mandalas are a kind of representation which is active, namely which helps synthetizing universals. Thought happens while we are drawing them and the actual drawing provides new general meaning. As explained elsewhere, I call "complete gesture" any action with a beginning and an end that implies a work through logical modalities (possibilities, actualities, generalities) and carries on a meaning (Maddalena 2015: 68-84). Existential graphs and mandalas can be complete gestures. They are synthetic, namely non-conceptual, tools that foster the knowledge of something new, not already included in the concept. In other words, they recognize an identity through changes. Existential graphs are apt to understand the logical transformation of an element into another, mandalas in Jung's theory permit to see the transformation that is happening through the self. Both of them are opening new ways for synthesis in a logical and a psychological way.

\section{Conclusions}

20 From a historical perspective, the first conclusion regards Peirce's philosophy. The American philosopher was eager to get rid of psychology because he wanted his analysis to be as pure as possible in order to get to the logical content of our knowledge. However, since he was a thorough analyst he could not avoid to consider some psychological elements like feelings, sensations, and habits as fundamental parts his epistemic path. But he decided to classify them as phenomenological items, leaving to psychology only a secondary role, as the science that presides over the study of the functioning of mind. However, this move testifies that Peirce's rich and pragmatist version of knowledge cannot eliminate those elements that we normally consider as psychological ones. Moreover, the kind of synthesis that his notes upon the semiotic elements of the existential graphs illuminate needs to be comprehensive of any part of our experience. Peirce stuck to an analysis of synthesis, but all of his philosophy, from the pragmatic maxim onward hints at a form of synthesis different from the Kantian one that depends on the form of analysis yet. Besides, Peirce wanted to have a synthesis which used synthetic tools as well; this is why he kept explaining the semiotic elements of the existential graphs. In these tools all elements of experience are included and psychological elements are no exception to this need.

21 From a psychological theoretical perspective, the use of existential graphs and mandalas as "complete gestures" suggests a direction also for analysis and can bridge two different psychological approaches. In fact, "complete gestures" hint towards a psychosynthesis in which we discover ourselves while doing something, in this case while drawing. Of course, this synthetic move is already part of Jung's approach to which Peirce's semiotic can provide a better understanding of symbolism and of the phenomenological/semeiotic/psychological reading of the teleological search for unity or selfhood. However, the rich phenomenological and semiotic background of pragmatism can also account for the "pragmatic" step that Jung himself considered unavoidable for a fulfillment of a creation of meaning. In this pragmatic solution, there is a synthesis and a balance obtained through "gestures," in which we understand that 
the "creation" of meaning is more a gesture within a tradition of symbols (unconscious and conscious) than a sporting out from nihil or an individualistic move. Moreover, we understand that this reaching for a meaning is not analytic in its origin. It is a synthetic move that happens in taking (synthetically) habits of action. Therefore, the philosophy of gesture could bridge Jung's analysis with the contemporary psychology behaviorism, avoiding the lack of meaning of the latter and the sometimes too vague theorization that afflicted the first raising of psychoanalysis at the beginning of the last century. ${ }^{12}$

\section{BIBLIOGRAPHY}

CALCATERRA R. M., (2003), Pragmatismo: I valori dell'esperienza, Roma, Carocci.

CALCATERRA R. M., (2004), “Forme e spazi di responsabilità. Postille alla logica normativa di Peirce," Semiotiche 2, 103-14.

COLAPIETRo V., (2000), "Further Consequences of a Singular Capacity," in J. Muller \& J. Brent (eds), Peirce, Semiotics and Psychoanalysis, Baltimore and London, The John Hopkins University Press.

Colapietro V., (2006), "Pragmatism and Psychoanalysis. C. S. Peirce as Mediating Figure," Cognitio, 7 (2), 189-205.

JAMES W., (1921/1907), Pragmatism. A New Name for Some Old Ways of Thinking, London, Longmans and Green.

JUNG C. G., (1983), Jung. Selected Writings, London, Fontana Press.

JUNG C. G., (2007), Gli archetipi dell'inconscio collettivo 1934/54, Torino, Bollati Boringhieri.

JUNG C. G., (2009), Tipi psicologici, Roma, Newton.

JUNG C. G., (2013), Gli archetipi del'inconscio collettivo, Torino, Bollati Boringhieri.

JUNG C. G., VON FRANZ M.-L., HENDERSON J. L., JACOBI J. \& A. JAFFÉ, (1964), Man and his Symbols, London, Aldus Books.

MAdDALENA G., (2008), "Un estremista dello scotismo: Charles S. Peirce," Quaestio: annuario di storia della metafisica, 8/2008, 569-84.

MADDALENA G., (2015), The Philosophy of Gesture, Montreal, McGill-Queen's University Press.

MAYORGA R., (2007), From Realism to "Realicism." The Metaphysics of Charles Sanders Peirce, Lankam, Lexington Books.

PEIRCE Charles S., (1931-35), Collected Papers, vols. I-VI, ed. by P. Weiss \& C. Hartshorne, Cambridge Mass, Harvard University Press.

PEIRCE Charles S., (1958), Collected Papers, vols. VII-VIII, ed. by A. W. Burks, Cambridge Mass, Harvard University Press.

PEIRCE Charles S., (1981-2010), Writings of Charles Sanders Peirce, vols. 1-6 \& 8, ed. by Peirce Edition Project, Indianapolis and Bloomington, Indiana University Press. 
PEIRCE Charles S., (1991-98), The Essential Peirce, vols. 1-2, ed. by Peirce Edition Project, Indianapolis and Bloomington, Indiana University Press.

SANTARelli M., (2017), "Security as Completeness. A Peircean Semotic Reading of the Psychology of Attachment," European Journal of Pragmatism and American Philosophy, 2017-1.

SEMETSKY I., (2002), "What Evil Lurks in the Hearts of Men? The Shadow," Trickster's Way, Vol. 1, Iss. 3, Article 2. Available at: [digitalcommons.trinity.edu/trickstersway/vol1/iss3/2].

SIMON R. J., (1967), “Great Paths Cross: Freud and James at Clark University, 1909," American

Journal of Psychiatry 124, 831-3.

SPINX C. W., (2003), "Peirce and Jung - Modern Gnostics in Search of Soul," Trickster's Way, Vol. 2, Iss. 4, Article 5. Available at: [digitalcommons.trinity.edu/trickstersway/vol2/iss4/5].

ZALAMEA F., (2010), Los grafico existenciales peirceanos, Bogotà, Universidad Nacional de Colombia.

\section{NOTES}

1. In that occasion James was favorably impressed by Jung while he thought Freud to be somehow "fixed" on his ideas (Colapietro 2006: 198).

2. Freud's comments on the meeting at Clark University were limited to an appraisal of James's "fearless" attitude since during a stroll they took together James had to face an angina pectoris attack (Simon 1967).

3. See Semetsky 2002 and Spinx 2003.

4. Colapietro (2006) correctly observes that Peirce is paradoxically the pragmatist who acknowledged the relevance of the unconscious.

5. See also Calcaterra (2003: 17-83).

6. For this definition see Maddalena (2015: 43-67).

7. A celebrated quote by Peirce can give the sense of his consideration of unconscious. "Consciousness is like a bottomless lake in which ideas are suspended at different depths. Indeed, these ideas themselves constitute the very medium of consciousness itself. Percepts alone are uncovered by the medium. We must imagine that there is a continual fall of rain upon the lake; which images the constant inflow of percepts in experience. All ideas other than percepts are more or less deep, and we may conceive that there is a force of gravitation, so that the deeper ideas are, the more work will be required to bring them to the surface" (CP7.533).

8. Freud's theoretical notions on the issue are obviously more complex when examined in detail. In The Ego and the Id (1923) Freud deals with a double characterization of the unconscious. Besides the repressed impulses there are also inherited unconscious representations that we inherit from our ancestors, as he made clear already in Totem and Taboo (1915). However, Jung's genetic explication of libido that famously interrupted the scholar partnership between Freud and Jung was a completely different kind of reading of the philogenesis of the unconscious.

9. For deepening the relationship between Duns Scotus's and Peirce's metaphysical realisms see Mayorga 2007, and Maddalena 2008.

10. For the relevance of quasi-mind for psychological approach see Colapietro 2000.

11. For a very interesting analysis of Peirce's entanglement of common sense, psychology, and logic see Calcaterra 2004.

12. See also Santarelli 2017. More in general, I thank Matteo Santarelli for insightful conversations and suggestions on this topic. 


\section{ABSTRACTS}

As correctly noticed by Vincent Colapietro, one of the few authors who have approached the topic, pragmatism and psychoanalysis followed parallel paths. The most obvious comparison between James and Freud did not seem to cast new light neither on the understanding of psyche nor on the two movements of thought. However, a different and less obvious comparison between Peirce and Jung might be more fruitful, notwithstanding the progressive antipsychologism of Peirce's approach to logic. As we are going to see, this unusual comparison is due to the strong epistemic and philosophical import of Jung's mature theories as well as to Peirce's tendency to provide a general theory of the mind, both conscious and unconscious. Therefore, this paper will try to understand the attitude that Peirce had towards psychology (I), to recall the part of Jung's theory that has to do with Peirce's pragmatism (II), to assess the relationship between the two authors and the reciprocal advantage in mutually integrating their theories (III).

\section{AUTHOR}

\section{GIOVANNI MADDALENA}

University of Molise

maddalena[at]unimol.it 